\title{
Spiritual transcendence as a buffer against death anxiety
}

\author{
Jarosław P. Piotrowski ${ }^{1}$ (D) - Magdalena Żemojtel-Piotrowska ${ }^{2} \cdot$ Amanda Clinton $^{3}$ \\ Published online: 27 February 2018 \\ (C) The Author(s) 2018. This article is an open access publication
}

\begin{abstract}
Terror Management Theory assumes the existence of two basic buffers against mortality salience: self-esteem and worldview. The aim of the current paper is to propose another buffer against mortality salience, namely spiritual transcendence. In the first study, we studied the impact of activation of spiritual transcendence as a moderator of mortality salience. Activating spiritual transcendence reduced the effect of the increase of the level of altruistic tendencies after exposure to mortality salience. In the second study, we replicated this finding based on the research procedures of former TMT research, using essay attacking participants' worldview. Results showed that spiritual transcendence acts as a buffer against mortality salience both among religious and non-religious individuals. Therefore, spiritual transcendence seems to be an additional buffer against mortality salience, independent from worldview and self-esteem, and it could be further examined from TMT perspective.
\end{abstract}

Keywords Terror management theory $\cdot$ Spiritual transcendence $\cdot$ Mortality salience

Although interest in the interrelationship between attitudes toward death and religiosity is not new (Lee et al. 2013; Neimeyer et al. 2004; Spilka et al. 2003), empirical research exploring the relationship between death anxiety and spirituality are relatively rare. Many studies addressing this issue focus on individuals or their families who are facing the end of life issues, and/or poorly distinguish between religiosity and spirituality (Cicirelli 2011; Currier et al. 2013; Doka 2011). In the past, Terror Management Theory (TMT) has evolved as one of the most important and dominant theories in the field of death anxiety. TMT offers an explanation of how religiosity may serve as a defensive mechanism that mediates mortality salience. This theory assumes the presence of two buffers, which could be labeled as "classical" - self-esteem and a personal worldview that potentially incorporates

Jarosław P. Piotrowski, Magdalena Żemojtel-Piotrowska and Amanda Clinton contributed equally to this work.

Jarosław P. Piotrowski jpiotrowski@swps.edu.pl

1 University of Social Sciences and Humanities, Poznań Faculty, Poznań, Poland

2 University of Cardinal Stefan Wyszynski, Warsaw, Poland

3 Psychology Department, University of Puerto Rico, Mayagüez, Puerto Rico religious beliefs - against the awareness of one's own death (Solomon et al. 1991, 2004). Both these buffers operate in a similar manner among all individuals, therefore they could be assumed to be universal ones.

In recent years, some alternative theories and additional buffers have been proposed. Meaning Maintenance Theory (Heine et al. 2006), for example, explains results obtained by TMT researchers as a general process, termed "fluid compensation". This process operates when the individual experiences situations they define as meaningless. Fluid compensation identifies mortality salience as one of many threats to meaning. There are also some alternative buffers against mortality salience proposed, such as symbolic immortality (Florian and Mikulincer 1998) or close relationships (Mikulincer et al. 2003). The aim of the current paper is to explore the role of a clearly defined new buffer against mortality salience: spiritual transcendence. First, we aimed to indicate that spiritual transcendence will reduce some of the typical effects of MS. Second, effects of spiritual transcendence was studied among believers and non-believers to indicate its independence from religiosity.

In the first study, we focused on identifying the role of activation of spiritual transcendence as a moderator of effects of mortality salience on prosocial behaviors. In the second study, we aim to replicate the findings of Greenberg et al. (1990), to indicate that spiritual transcendence acts as a buffer against mortality salience both among religious and nonreligious individuals as it inhibits increasing negative 
evaluation of anti-Polish essay (and its author) after exposure to mortality salience.

\section{Terror Management Theory and Buffers against Mortality Salience}

Terror Management Theory (TMT) assumes the existence of self-esteem as an individual buffer and a shared worldview as a cultural buffer against awareness of one's own mortality. Numerous studies present the effects of mortality salience (Greenberg et al. 1990; Lifshin et al. 2017; Rosenblatt et al. 1989; Wilson and Bernas 2011). In addition, the authors differentiate between proximal and distal defense mechanisms as buffers to fear of death and dying (Pyszczynski et al. 1999). The question of whether buffers proposed by TMT are unique is not new (Florian and Mikulincer 1998). The oldest and best known among other potential buffers is the searching for meaning in life (Frankl 1963; Maddi 1970). Florian and Mikulincer (1998) as based on Lifton's (1979) work, focus on personal continuity and transcendence as defense mechanisms against death anxiety. They operationalize this mechanism as symbolic immortality. According to Lifton (1979), symbolic immortality is a result of interpreting life in different ways: (1) the sense of generational continuity from the past to the present; (2) the sense that one's own works will pertain after his or her death; (3) the sense that the individual is a part of universe which transcends a single being; (4) the sense that death can transcend via religiosity and spirituality; (5) the sense that individuals can lose themselves in experiences of optimal performance or other flow experiences. Symbolic immortality could be expressed in many forms, as the urgency to having children (Conrad 2009) or engaging in collective action (Elad-Strenger 2016). Interestingly, symbolic immortality has much in common with spiritual transcendence (Piedmont 1999), despite Piedmont did not refer to this construct in his works. Therefore, as spiritual transcendence is a well-defined and established psychological construct, it would offer an interesting supplementation to the former works on symbolic immortality as a possible defense mechanism against mortality salience.

\section{Spiritual Transcendence as Plausible Buffer against Mortality Salience}

Spiritual transcendence (ST), such as defined by Piedmont (1999), is particularly promising as a possible buffer against mortality salience since it is assumed to be culturally universal in that it constitutes a basic personality trait and has a visible motivational aspect. Spiritual transcendence "refers to the capacity of individuals to stand outside of their immediate sense of time and place to view life from a larger, more objective perspective" (Piedmont 1999, p. 988). Spiritual transcendence is a multi-faceted personality trait, constituted by prayer fulfillment, the ability to create a personal space that enables one to feel a positive connection to some larger reality; universality, the belief in a larger meaning and purpose to life; and connectedness, feelings of belonging and responsibility to a larger human reality that cuts across generations and groups (Piedmont 2010, 2012).

Religion is only one of the ways in which motivation associated to ST can find expression (Piedmont 1999, 2001). As a result, it is possible that atheistic individuals could manifest high levels of spirituality, but it will be associated with domains other than religious. Therefore, we postulate that two main forms of ST could be distinguished. The first one may be called a religious transcendence and encompasses those forms of spiritual transcendence that are associated with belief in a Higher Being as well as the afterworld, prayer, and other religiously related content. The second form may be called a nonreligious transcendence and it encompasses all forms of ST which are not associated with the religious content. One example of a non-religious transcendence is connectedness, or "a belief that one is part of a larger human orchestra" (Piedmont 1999, p. 989) while another example is universality - "a belief in the unitive nature of life" (p. 989). These two forms could be empirically distinguished. For instance, only a non-religious form of spiritual transcendence inhibits spending money on status-related goods (an expression of materialism) in mortality salience condition, whilst religious form does not (Żemojtel-Piotrowska and Piotrowski 2016).

Florian and Mikulincer (1998) indicated that symbolic immortality could serve as a defense mechanism against mortality salience. Symbolic immortality, however, seems not to be a universal buffer, contrary to the classical buffers: self-esteem and shared worldview proposed by Solomon et al. (1991). Symbolic immortality is related to some kind of worldview, as it is a specific conviction about the nature of human life and it is a part of many religious systems (Lifton and Olson 1974). Effects of symbolic immortality on mortality salience were observed only among persons who hold this belief (i.e., among individuals who had high levels of this conviction, see Florian and Mikulincer 1998). On the other hand, Meaning Maintenance Model describes a very general mechanism of reaffirming others that are not directly related to mental representation and allows for the inclusion of nearly any set of buffers in its description.

As explained by Florian and colleagues, spiritual transcendence operates in a similar manner since it allows for symbolic immortality due to transcending individual experience (by establishing a symbolic bond between self and universe or connectedness to other human beings). However, contrary to Florian and Mikulincer, we expect that spiritual transcendence is a universal mechanism, in this regard that it operates in a similar manner among people who are believers and non- 
believers. Furthermore, we consider two forms of spiritual transcendence, in religious and a non-religious form. Because in the classic version of TMT, religion could be regarded as a type of worldview, indicating that only religiously infused spiritual transcendence serves as a defense mechanism against mortality salience is not convincing. For instance, Dechesne et al.' (2003) studies on literal immortality showed that when participants read an essay describing scientific evidence supporting the existence of life after death, the effect of mortality salience disappeared. For this reason, we do not discard the alternative explanation that spiritual transcendence in a religious form is a unique and exclusive worldview. However, we expect that spiritual transcendence in a nonreligious form also reduces anxiety related to death subsequent to being exposed to content that evokes awareness of one's own mortality.

Based on the review done above, following research questions have been asked: (1) will spiritual transcendence activation work as a moderator of effects of mortality salience on prosocial behaviors and worldview defense? (2) will the effects of spiritual transcendence activation be the same for believers and non-believers?

\section{Study 1}

This study aimed to check if spiritual transcendence acts as a buffer against mortality salience, i.e. reduces the typical effect of MS. Previous studies have documented increases in altruistic behavior when mortality salience is activated (Hirschberger et al. 2008; Wilson and Bernas 2011). Therefore, we activated mortality salience and then spiritual transcendence and contrasted this manipulation with mortality salience condition without spiritual transcendence activation and with the control condition. We expected that the tendency for altruistic behavior will be higher in the mortality salience condition than in the control group while in the group with activated death anxiety followed by activation of spiritual transcendence, the level of this tendency will be the same as in the control condition. We did not formulate expectations toward the main effect of spiritual transcendence on helping behaviors because the relationship between these variables was irrelevant for our research problem.

\section{Method}

\section{Participants}

The sample consisted of 140 high school students (101 women, $M_{\text {age }}=17.31, S D=0.66$ ) from Poland. The study was anonymous and had no time limits. Informed consent was obtained from all individual participants included in this study.

\section{Procedure and Materials}

The study was designed on between-subject comparisons, according to experimental 2 (mortality salience: present vs. absent) $\times 3$ (spiritual transcendence (ST): a religious form vs. a non-religious form vs. absent) design.

Activating of mortality salience was based on Greenberg et al. (1990) research procedure. Participants were asked to write up an answer to two questions. In the mortality salience condition, participants were asked to write about the emotions that accompany thoughts of their own death, and what would happen to their bodies after they die. In the control condition, participants were asked to write about the emotions they feel when they watch TV and what happens to their bodies when they ride a bicycle.

Activating religious and non-religious transcendence was based on analogical procedure. In the religious transcendence condition, participants were asked to write up answers on following questions: (1) "describe as detailed as you can, what traits would God have if he was a human"; and (2) "what emotions do you feel while you are praying? If you do not pray, what do you think, what emotions people who do pray feel?". In the non-religious transcendence condition, participants were asked to (1) "describe as detailed as you can, what you have in common with other people, those who lived before you, who are living now, and who will live in the future" and (2) "what emotions do you feel while thinking about being a part of the universe". Participants in the control conditions were asked to: (1) "describe as detailed as you can, what happens with your body during ice skating"; (2) "what emotions do you feel while you think about your typical day?"

Each student was asked if they would be willing participants in an experiment about "imagination and social beliefs" when they volunteered. Then participants were randomly assigned to one of six conditions: (1) mortality salience (MS); (2) religious spiritual transcendence (RST); (3) nonreligious spiritual transcendence (NST); (4) mortality salience followed by RST; (5) mortality salience followed by NST; (6) control condition. In each one condition participants answered four questions. In mortality salience condition participants answered questions activating MS and two control questions: one about ice skating and one about a typical day. In RST and NST conditions they answered two questions related to activating ST (each form respectively) and then answered questions about watching TV and riding a bicycle. In the control condition, they answered all four control condition questions.

Upon assignment to groups they were presented with an information: "In our city, we have a local therapeutic 
center working for children from our local community". Then they were asked how many hours of their own time they would be willing to contribute toward helping the children who receive services at this therapeutic center (open answer).

Pre-Test A pilot study was conducted in order to test the effectiveness of spiritual transcendence manipulation. One hundred twenty university students ( 80 females, 32 males, Mage $=22.26, S D=2.41$ ) participated in the study as a part of their psychology course. After activating spiritual transcendence in religious and non-religious form (in the manner described earlier), participants were asked to complete the Scale of Spiritual Transcendence (Piotrowski et al. 2013). This scale contains 22 questions measuring spiritual transcendence as described in Piedmont's (1999) theory. The Scale of Spiritual Transcendence has high reliability $(\alpha=.87)$ and confirmed validity. In order to check for manipulation effectiveness, planned contrast comparing two ST conditions against control the group were conducted. Analyses showed that, confirming manipulation effectiveness, participants had higher scores in SST after religious $(M=74.10, S D=$ $7.31)$ or non-religious $(M=71.31, S D=11.36)$ ST activation as compared to the control group $(M=49.28$, $S D=5.55), t(101.80)=16.80, p<.001, d=2.65$. Moreover, there was no difference between a religious and a non-religious ST conditions, $p=.199$.

\section{Results}

In order to examine changes in altruistic behavior after experimental manipulation, a $2 \times 3$ ANOVA was completed. There were no main effects of mortality salience, $F(1,134)=0.56$, $p=.455$, or spiritual transcendence, $F(2,134)=1.11, p=.333$. Analyses showed only the predicted interaction between mortality salience and spiritual transcendence, $F(2,134)=$.

3.93, $p=.021, \eta^{2}=.06$. Post-hoc comparisons showed that in the condition without spiritual transcendence, mortality salience increased one's readiness for altruistic behavior, $p=.016$. In the condition of religious transcendence, there was no effect of mortality salience on altruistic behavior, $p=.303$. There was also no effect of mortality salience on altruistic behavior in the condition of non-religious transcendence, $p>.339$. Results are presented in Fig. 1. Our results demonstrate that spiritual transcendence in both religious form and non-religious form acts as a buffer against death anxiety. The effect of transcendence on altruistic behavior was insignificant, indicating that spiritual transcendence just reduces the effect of activating mortality salience.

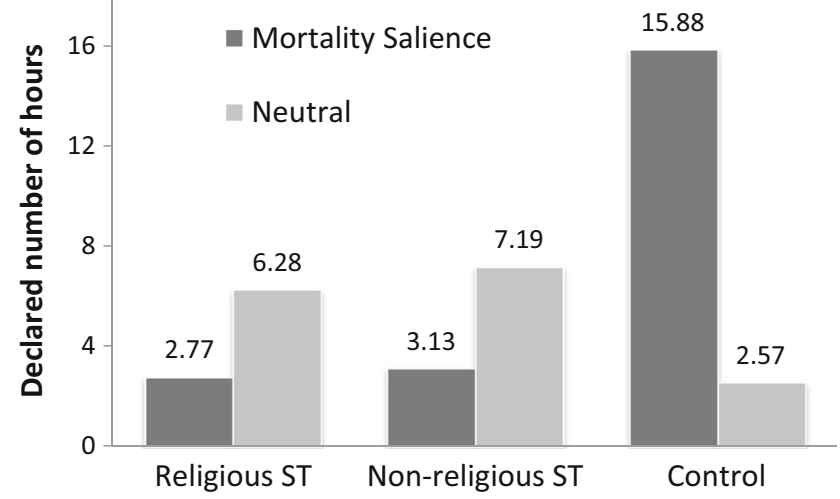

Fig. 1 Effects of mortality salience and spiritual transcendence on altruistic behavior

\section{Study 2}

In Study 1, we showed that spiritual transcendence acts as a buffer against mortality salience. However, our procedure and dependent variable were rather atypical as compared to classic studies such as those reported by Greenberg et al. (1990) and Solomon et al. (1991). Moreover, we did not indicate that spiritual transcendence is truly a universal (i.e., present among all individuals) buffer since we did not control for the religiosity of our participants. For these reasons, one could expect that spiritual transcendence might act as a buffer against mortality salience only among religious individuals. To rule out this possibility in Study 2, we adhered to the procedure reported by TMT authors and conducted research employing a sample of individuals from the general population in Poland who expressed faith in a higher power and those who indicated they are non-believers. We expected that spiritual transcendence in nonreligious form would act as a buffer against mortality salience both among believers and atheists, congruent with an assumption about universal character of spirituality as a personal trait, not related to religious beliefs (Piedmont 1999).

\section{Method}

\section{Participants}

Two hundred and twelve (115 women, $M_{\mathrm{age}}=27.20, S D=$ 5.50) Polish users of the internet panel Ariadna participated in the study in exchange for receiving points in the panel's loyalty program. One hundred twenty-eight of the participants identified as Christians (mostly Catholics, as this denomination prevails in Polish society) while 84 described themselves as atheists. 


\section{Procedure and Materials}

Participants were randomly assigned to one of the following conditions, according to the 2 (atheist vs. Catholic) $\times 2$ (mortality salience: present vs. absent) $\times 3$ (spiritual transcendence: in religious form vs. in non-religious form vs. absent) experimental design. Subsequent to the assignment, all participants completed a filler task, i.e., the scale used in measuring the response styles labeled as "Preferences Scale" (Jakubowska 2005). At the last stage of the study, participants read an essay attacking Polish worldview, in which the author discussed the limited and unimportant role of Polish culture in the world. After reading the essay, participants answered questions about it and about its author. Activation of mortality salience and spiritual transcendence were identical to Study 1.

After assignment to the one of six experimental condition and answering on four questions (see Study 1), participants responded to 10 items of filler task (e.g., "I prefer modern furniture over classical ones"; or "Dogs are more friendly than cats") with Likert scale format response options ranging from 1 (definitely not) to 7 (definitely yes). Finally, they read a onepage long anti-Polish essay (in analogy to anti-American essay used by Greenberg et al. 1990) and were asked six questions with Likert scale format response options ranging from 1 (definitely not) to 6 (definitely yes). The six items are as follows: (1) Author has wide knowledge on the topic, (2) Essay is written in clear, elegant language, (3) I agree with the author's point of view, (4) The essay is true and accurate, (5) Author of the essay seems to be a nice person, (6) The author of the essay seems to be an intelligent person. These six questions created a scale measuring attitude toward essay. Higher results on this scale (mean scores) indicate a more positive evaluation of the author and the essay. Reliability of this scale was high, $\alpha=0.89$.

\section{Results}

Scores of the scale measuring attitude toward the author of the anti-Polish essay were subjected to a $2 \times 2 \times 3$ ANOVA. There were no main effects of mortality salience, $F(1,200)=0.16, p$ $=.686$, nor spiritual transcendence on assessment of the antiPolish essay, $F(2,200)=0.44, p=.647$. There was an unexpected main effect for being an atheist, $F(1,200)=$ 5.52, $p=.020, \eta^{2}=0.03$. Believers evaluated both the essay and author more positively $(M=4.07, S D=0.68)$ than atheists $(M=3.85, S D=0.85)$.

Analyses showed the predicted interaction between mortality salience and spiritual transcendence, $F(2,200)=3.65, p=$ $.028, \eta^{2}=0.04$. Post-hoc comparisons further demonstrated that in the condition without spiritual transcendence, mortality salience resulted in the more negative evaluation of the antiPolish essay, $p=.048$, showing the direction of the predictions. In the condition of religious transcendence, there was no effect of mortality salience on evaluation, $p=.131$. There was also no effect of mortality salience on evaluation in the condition of non-religious transcendence, $p=.298$. Overall, results indicate that spiritual transcendence acts as a buffer against mortality salience irrespective of its form. Results (without split for Catholics and atheists) are presented in Fig. 2.

No significant interactions were observed between being an atheist and mortality salience, $F(2,200)=0.13, p=.723$, and between being an atheist and spiritual transcendence, $F(2$, $200)=2.98, p=.053$. There was also no interaction between mortality salience, spiritual transcendence and being an atheist, $F(2,200)=0.73, p=.483$. Overall, findings demonstrate that spiritual transcendence acts as a buffer against mortality salience both among believers and non-believers.

\section{Discussion}

In both studies, activation of spiritual transcendence when participants were confronted with their own mortality protected against effects typically observed after activating death anxiety: altruistic behavior (Study 1) and a decrease in the evaluation of essay (and its author) attacking personal worldview (Study 2). No differences between religious and non-religious form were found in either study and in Study 2 religious identity did not affect the results. This last result suggests that spiritual transcendence could be a universal buffer, as it works among all individuals, regardless of their religiosity level.

Our findings are similar to results from prior studies that suggest spiritual transcendence acts as a buffer against mortality salience (Żemojtel-Piotrowska and Piotrowski 2016). The present work expands upon previous papers in terms of symbolic immortality (Florian and Mikulincer 1998) and literal immortality (Dechesne et al. 2003) since the spiritual transcendence concept offers a more in-depth explanation of

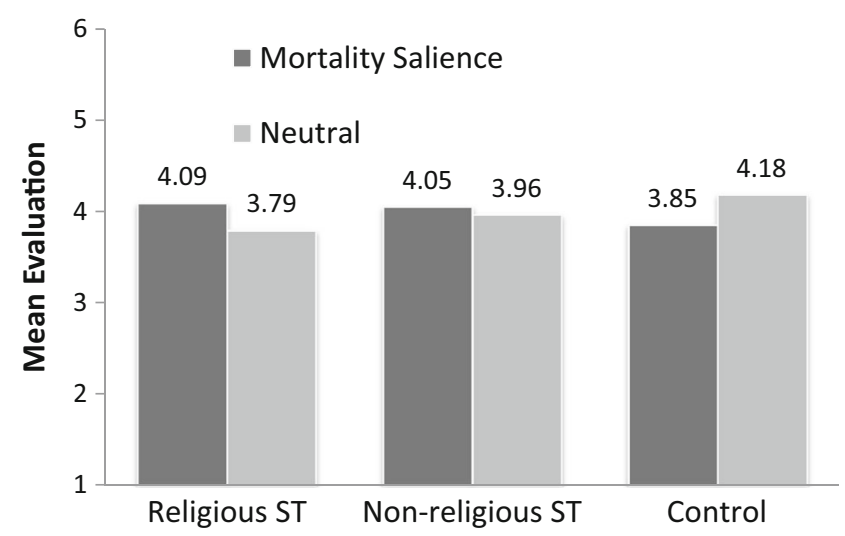

Fig. 2 Effects of mortality salience and spiritual transcendence on the evaluation of anti-Polish essay and its author 
why this phenomenon could serve as an additional buffer against mortality salience. First, spiritual transcendence is independent of self-esteem and personal world-view, as it is not related to religion, it is universal, and, as proven by Piedmont (1999), it is a basic personality trait. On the other hand, it is possible that spiritual transcendence acts as a buffer against mortality salience because it allows for experiencing symbolic immortality (Lifton 1979) or even a belief in literal immortality. This last possibility requires further research. Also, our results are congruent with those found by Mikulincer et al. (2003) on the importance of close relationships. Connectedness, a component of spiritual transcendence, assumes positive bonds with other people. Therefore, experiencing close relationships could serve as a buffer against mortality salience due to experiencing some sort of exceeding self, via a relationship with closest ones, as well as with broader community, or even universe.

\section{Limitations}

The number of participants was small (and, in the first study, participants belonged to narrowly specified part of the population). On the other hand, samples were big enough to yield statistically significant results, congruent with our predictions. Also, while the experimental manipulation was either devised by other researchers (Greenberg et al. 1990) or validated in a pilot study (in case of spiritual transcendence manipulation), measures of independent variables were used in described studies alone. However, we do not aim to revise TMT or discuss if alternative theories explaining coping with awareness of own mortality (like MMT) offers a better explanation in comparison to TMT. It is the question for future research. It is also recommended to replicate our findings on other effects related to TMT, like higher performance in sports (Zestcott et al. 2016) or more positive attitude towards killing the animals (Lifshin et al. 2017).

Funding The research was supported by National Science Center Grant number 2017/01/X/HS6/01320

\section{Compliance with Ethical Standards}

Ethical Approval All procedures performed in studies involving human participants were in accordance with the ethical standards of the institutional and/or national research committee and with the 1964 Helsinki declaration and its later amendments or comparable ethical standards. Informed consent: Informed consent was obtained from all individual participants included in the study.

Conflict of Interest On behalf of all authors, the corresponding author states that there is no conflict of interest.
Open Access This article is distributed under the terms of the Creative Commons Attribution 4.0 International License (http:// creativecommons.org/licenses/by/4.0/), which permits unrestricted use, distribution, and reproduction in any medium, provided you give appropriate credit to the original author(s) and the source, provide a link to the Creative Commons license, and indicate if changes were made.

\section{References}

Cicirelli, V. G. (2011). Religious and nonreligious spirituality in relation to death acceptance or rejection. Death Studies, 35, 124-146. https:// doi.org/10.1080/07481187.2011.535383.

Conrad, B. (2009). Terror management theory and the impact of individual and collective mortality salience on symbolic and literal immortality beliefs. Dissertation Abstracts International: Section B: The Sciences and Engineering, 75, 7-B (E).

Currier, J. M., Mallot, J., Martinez, T. E., Sandy, C., \& Neimeyer, R. A. (2013). Bereavement, religion, and posttraumatic growth: A matched control group investigation. Psychology of Religion and Spirituality, 5(2), 69-77. https://doi.org/10.1037/a0027708.

Dechesne, M., Pyszczynski, T., Arndt, J., Ransom, S., Sheldon, K. M., van Knippenberg, A., \& Janssen, J. (2003). Literal and symbolic immortality: The effect of evidence of literal immortality on selfesteem striving in response to mortality salience. Journal of Personality and Social Psychology, 84(4), 722-737. https://doi. org/10.1037/0022-3514.84.4.722.

Doka, K. J. (2011). Religion and spirituality: Assessment and intervention. Journal of Social Work in End-of-Life \& Palliative Care, 7, 99 109.

Elad-Strenger, J. (2016). Activism as a heroic quest for symbolic immortality: An existential perspective on collective action. Journal of Political and Social Psychology, 4, 44-65. https://doi.org/10.5964/ jspp.v4i1.430.

Florian, V., \& Mikulincer, M. (1998). Symbolic immortality and the management of the terror of death: The moderating role of attachment style. Journal of Personality and Social Psychology, 74(3), 725734. https://doi.org/10.1037/0022-3514.74.3.725.

Frankl, V. E. (1963). Man's search for meaning. Boston: Beacon Press.

Greenberg, J., Pyszczynski, T., Solomon, S., Rosenblatt, A., Veeder, M., Kirkland, S., \& Lyon, D. (1990). Evidence for terror management theory II: The effects of mortality salience on reactions to those who threaten or bolster the cultural worldview. Journal of Personality and Social Psychology, 58(2), 308-318. https://doi.org/10.1037/ 0022-3514.58.2.308.

Heine, S. J., Proulx, T., \& Vohs, K. D. (2006). The meaning maintenance model: On the coherence of social motivation. Personality and Social Psychological Review, 10(2), 88-111. https://doi.org/10. 1207/s15327957pspr1002_1.

Hirschberger, G., Ein-Dor, T., \& Almakias, S. (2008). The self-protective altruist: Terror management and the ambivalent nature of prosocial behavior. Personality and Social Psychology Bulletin, 34(5), 666 678. https://doi.org/10.1177/0146167207313933.

Jakubowska, U. (2005). Ekstremizm polityczny: studium psychologiczne. Gdańsk: GWP.

Lee, S., Piotrowski, J., Różycka, J., \& Żemojtel-Piotrowska, M. (2013). Associations between death fascination, death anxiety, and religion. Polish Psychological Bulletin. https://doi.org/10.2478/ppb-20130047.

Lifshin, U., Greenberg, J., Zestcott, C. A., \& Sullivan, D. (2017). The evil animal: A terror management theory perspective on the human tendency to kill animals. Personality and Social Psychology Bulletin, 43(6), 743-757. 
Lifton, R. J. (1979). The broken connection. New York: Simon \& Schuster.

Lifton, R. J., \& Olson, E. (1974). Symbolic immortality. In R. J. Lifton \& E. Olson (Eds.), Living and dying. London: Wildwood House.

Maddi, S. (1970). The search for meaning. In W. J. Arnold \& M. M. Page (Eds.), Nebraska symposium on motivation (pp. 137-186). Lincoln: University of Nebraska Press.

Mikulincer, M., Florian, V., \& Hirschberger, G. (2003). The existential function of close relationships: Introducing death into the science of love. Personality and Social Psychology Review, 7, 20-40.

Neimeyer, R. A., Wittkowski, J., \& Moser, R. P. (2004). Psychological research on death attitudes: An overview and evaluation. Death Studies, 28, 309-340. https://doi.org/10.1080/07481180490432324.

Piedmont, R. (1999). Does spirituality represent the sixth factor of personality? Spiritual transcendence and the five-factor model. Journal of Personality, 67, 985-1013. https://doi.org/10.1111/1467-6494. 00080.

Piedmont, R. (2001). Spiritual transcendence and the scientific study of spirituality. Journal of Rehabilitation, 67(1), 4-14.

Piedmont, R. L. (2010). Assessment of spirituality and religious sentiments. Technical manual. 2nd edn. Timonium: published by author.

Piedmont, R. L. (2012). Overview and development of measure of numinous constructs: The Assessment of Spirituality and Religious Sentiments (ASPIRES) Scale. In: The Oxford handbook of psychology and spirituality (pp. 104-122).

Piotrowski, J., Skrzypińska, K., \& Żemojtel-Piotrowska, M. (2013). The scale of spiritual transcendence: Construction and validation. Annals of Psychology (Roczniki Psychologiczne), 16(3), 451-467.

Pyszczynski, T., Greenberg, J., \& Sheldon, S. (1999). A dual-process model of defense against conscious and unconscious death-related thoughts: An extension of terror management theory. Psychological
Review, 106(4), 835-845. https://doi.org/10.1037/0033-295X.106. 4.835 .

Rosenblatt, A., Greenberg, J., Solomon, S., Pyszczynski, T., \& Lyon, D. (1989). Evidence for terror management theory: I. The effects of mortality salience on reactions to those who violate or uphold cultural values. Journal of Personality and Social Psychology, 57(4), 681-690. https://doi.org/10.1037/0022-3514.57.4.681.

Solomon, S., Greenberg, J., \& Pyszczynski, T. (1991). A terror management theory of social behavior: The psychological functions of selfesteem and cultural worldviews. In M. E. P. Zanna (Ed.), Advances in experimental social psychology (Vol. 24, pp. 91-159). San Diego: Academic Press.

Solomon, S., Greenberg, J., \& Pyszczynski, T. (2004). Twenty years of terror management theory. In J. Greenberg, S. L. Koole, \& T. Pyszczynski (Eds.), Handbook of experimental existential psychology (pp. 13-34). New York: Guilford Press.

Spilka, B., Hood, R. W., Hunsberger, B., \& Gorsuch, R. (2003). The psychology of religion: An empirical approach (3rd ed.). New York: The Guilford Press.

Wilson, K. M., \& Bernas, R. (2011). A good man is hard to find: Forgiveness, terror management, and religiosity. Research in the Social Scientific Study of Religion, 22, 126-140.

Żemojtel-Piotrowska, M., \& Piotrowski, J. (2016). Spiritual transcendence, mortality salience and consumer behaviors: Is spirituality really opposite to materialism? International Journal of Psychology and Behavioral Analysis, 2, 112. https://doi.org/10. 15344/2455-38267/2016/112.

Zestcott, C. A., Lifshin, U., Helm, P., \& Greenberg, J. (2016). He dies, he scores: Evidence that reminders of death motivate improved performance in basketball. Journal of Sport \& Exercise Psychology, 38(5), 470-480. https://doi.org/10.1123/jsep.2016-0025. 